Article

\title{
Optimization of Enzymatic Production of Oligopeptides from Apricot Almonds Meal with Neutrase and N120P
}

\section{Chunyan Wang, Qiang Wang * and Jinqiang Tian}

Institute of Agro-food Science and Technology, The Key Laboratory of Agro-food Process and Quality Control, Ministry of Agriculture, Chinese Academy of Agriculture Science, 2 Yuanmingyuanxi Road, Beijing 100193, China; E-Mails: wchunyan001@163.com (C.W.); tianjinqiang1971@163.com (J.T.)

* Author to whom correspondence should be addressed; E-Mail: caaswangqiang@hotmail.com; Tel.: +86-10-6281-5844; Fax: +86-10-6281-5837.

Received: 9 October 2010; in revised form: 28 October 2010 / Accepted: 10 November 2010 / Published: 2 December 2010

\begin{abstract}
Neutrase 0.8L and N120P proteases were used for oligopeptide production from apricot almonds meal, and response surface design was carried out to optimize the effect of hydrolysis conditions on hydrolysis degree $(\mathrm{DH})$ and oligopeptide yield rate. Four independent variables were used to optimize the hydrolysis process: hydrolysis temperature $\left(X_{1}\right)$, enzyme-to substrate ratio $(\mathrm{E} / \mathrm{S})\left(X_{2}\right)$, substrate concentration $\left(X_{3}\right)$ and reaction time $\left(X_{4}\right)$. Statistical analysis indicated that the four variables, quadratic terms of $X_{1}, X_{3}$, and $X_{4}$, and the interaction terms with $\mathrm{X}_{1}$ had a significant $(p<0.05)$ effect on $\mathrm{DH}$. The yield rate was also significantly affected by the four variables and quadratic terms of $X_{1}, X_{2}$ and $X_{4}$. Two mathematical models with high determination coefficient were obtained and could be employed to optimize protein hydrolysis. The optimal hydrolysis conditions were determined as follows: hydrolysis temperature $52.5^{\circ} \mathrm{C}$; enzyme-to-substrate ratio $(\mathrm{E} / \mathrm{S}) 7200 \mathrm{U} / \mathrm{g}$; substrate concentration $2 \%$; reaction time $173 \mathrm{~min}$. The initial $\mathrm{pH} 6.5$ and Neutrase-to-N120P dosage ratio 2:1 were fixed in this study according to the preliminary research. Under these conditions, the experimental DH and yield rate were $34.10 \pm 5.25 \%$ and $72.42 \pm 2.27 \%$, respectively.
\end{abstract}

Keywords: apricot almonds meal; enzymatic production; hydrolysis; oligopeptides 


\section{Introduction}

The apricot is a member of the Rosaceae, subfamily Prunoideae. It is widely grown in Asia, the Mediterranean region and the United States of America. The apricot almond constitutes an important part of the human diet. They are typically used as snack foods or as ingredient in a variety of processed foods, especially in bakery and confectionery products [1,2]. In recent years, apricot kernels are used in the production of oils, benzaldehyde, cosmetics, aroma perfume, and active carbon [3,4]. Almond contains $15-30 \%$ protein and its amino acid composition is found to be balanced [5]. Defatted almonds meal (DAM) contains $41.5 \%$ total protein and the amount of it remaining after processing is quite large, so almond meal could be used as a good source of protein [5]. The research of almond protein mainly focuses on physico-chemical and functional properties and the protein allergy [6,7]. There are few studies on deep processed dietary protein production in the waste of DAM, and just a small part of it was used to produce livestock feed. Therefore, it is necessary to research how to utilize DAM.

During the last decade, many bioactive peptides have been discovered from enzymatic hydrolysate of different food proteins, including mineral binding peptides, immunomodulatory peptides [8], antibacterial peptides [9], antithrombotic peptides [10], and antihypertensive peptides [11,12]. To our knowledge, most of these peptides are prepared by enzyme hydrolysis; in addition small peptides are better absorbed than proteins and free amino acids [13,14]. Therefore, a high degree of hydrolysis (DH) and high peptide yield rates are desirable.

In the process of hydrolysis, the influence of hydrolysis parameters, including temperature, enzyme-to-substrate $(\mathrm{E} / \mathrm{S})$ ratio, substrate concentration and hydrolysis time and the interactive effects between hydrolysis parameters on $\mathrm{DH}$ and peptide yield rate have to be considered. In order to optimize hydrolysis conditions and establish predictive models of the effects of various hydrolysis parameters on the $\mathrm{DH}$ and yield rate of almond oligopeptides, the hydrolysis process has to be further investigated. Response surface modeling has proven to be an effective statistical technique for optimizing complex processes [15].

The major goal of this study was to use Neutrase $0.8 \mathrm{~L}$ and N120P to produce oligopeptides from DAM. Also, a study of response surface design was carried out to examine the effect of hydrolysis parameters such as hydrolysis temperature, enzyme-to-substrate (E/S), substrate concentration, hydrolysis time and their interactive effects on DH and oligopeptide yield rate. Furthermore, the predictive models and optimal condition of the hydrolysis process were established through response surface analysis in order to obtain high $\mathrm{DH}$ and high oligopeptide yield rate. To our knowledge, there have been little studies on peptides derived from almond protein.

\section{Results and Discussion}

\subsection{Analysis of Response Surface}

The relationship between independent and dependent variables is illustrated in tri-dimensional representation of the response surfaces generated by the model for DH (Figure 1). Due to the same trend of variables affecting DH and almond oligopeptide (AOP) yield rate (Equations (1), (2) and Table 3), only the response surface analysis of $\mathrm{DH}$ was performed. Two variables were depicted in one tri-dimensional surface plot while the other variables were kept at level zero. With the changing of the 
variables, the variation of DH was significant. It is clear that the DH was sensitive to alteration of the test variables.

Figure 1. Response surfaces for the interaction of variables on DH. The response surface plots at various (a) temperatures and E/S; (b) temperatures and substrate concentrations; (c) temperatures and reaction times; (d) E/S and substrate concentrations; (e) $\mathrm{E} / \mathrm{S}$ and reaction times; and (f) substrate concentrations and reaction times.

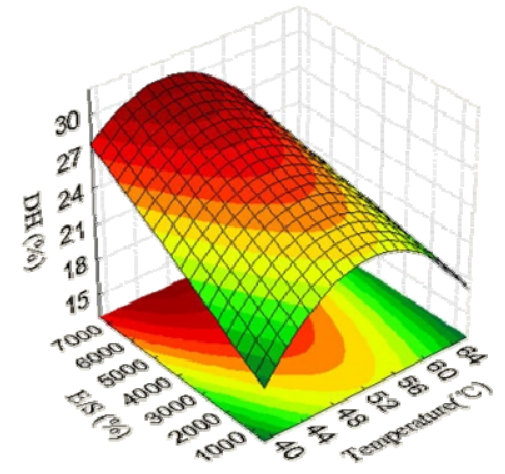

a

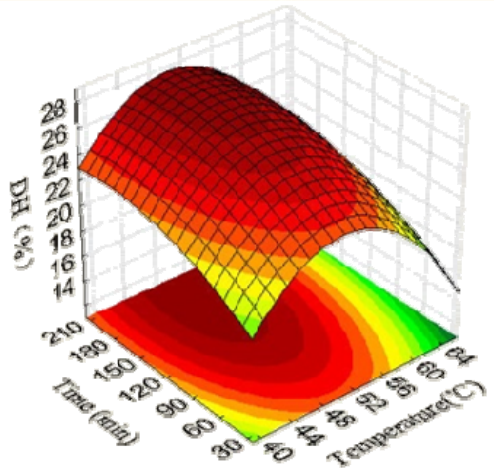

C

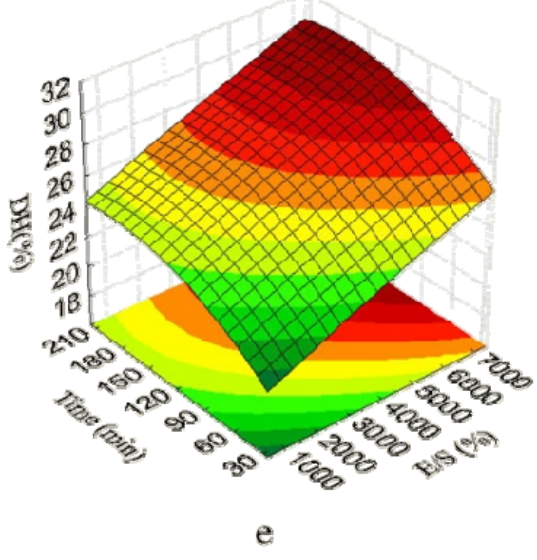

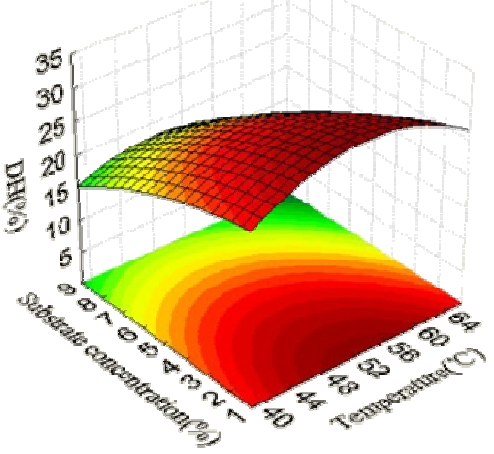

b
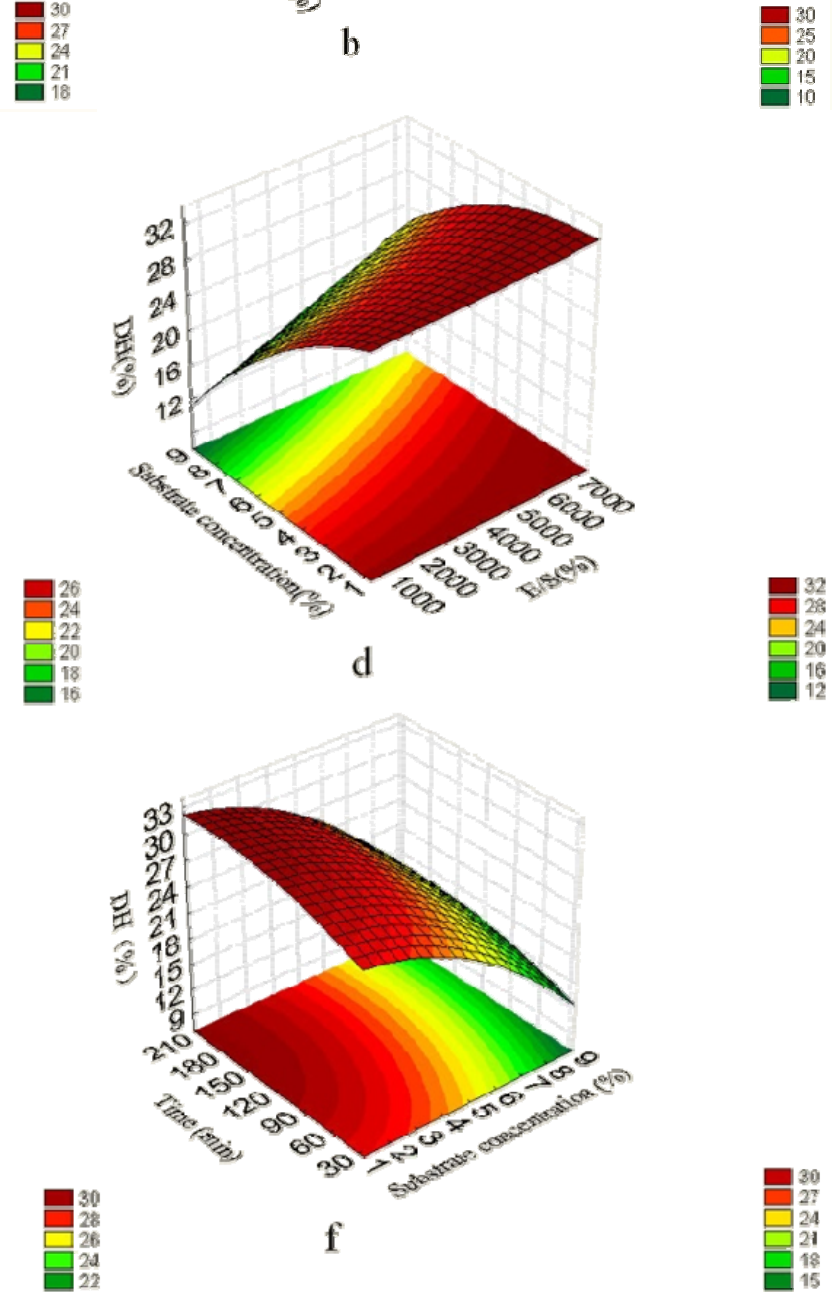

The effect of the interaction relationship of temperature with $\mathrm{E} / \mathrm{S}$, substrate concentration and reaction time on $\mathrm{DH}$ are shown in Figure 1a-c, respectively, which together indicate that these four variables all significantly affected DH. As shown in Figure 1a-c, the DH enhanced rapidly with an 
increase in temperature and reached a peak value at $52.5^{\circ} \mathrm{C}$. With further temperature increases, the $\mathrm{DH}$ decreased significantly. $\mathrm{E} / \mathrm{S}$ and reaction time had a positive effect on $\mathrm{DH}$, while the $\mathrm{DH}$ decreased when the substrate concentration was in the range of $2-8 \%$. Longer reaction times and higher E/S had positive effects on the yield extraction, and reached a critical value at 173 min and 5851 units $\mathrm{g}^{-1}$ protein, respectively, when at a constant temperature $\left(52.5^{\circ} \mathrm{C}\right)$. This suggested the higher $\mathrm{DH}$ resulted at a medium temperature, higher $\mathrm{E} / \mathrm{S}$, longer reaction time and lower substrate concentration.

It is considered that a higher $\mathrm{DH}$ at higher $\mathrm{E} / \mathrm{S}$ is due to the increase of the contact chance of enzyme and protein and enhanced concentration of peptide bonds susceptible to hydrolysis by the proteases. The same results were obtained by Zhang et al. and Wang et al. [16,17]. For the substrate concentration, a negative effect on DH was observed due to the higher substrate concentration leading to a decrease in water activity, and the substrate may play a part in deactivating the enzyme at the lower water activity, which is in accordance with other studies $[18,19]$.

The effect of E/S, substrate concentration and reaction time are illustrated in the response surface plots. It is shown that the interactions between the $\mathrm{E} / \mathrm{S}$ and other two variables did not impact the $\mathrm{DH}$ significantly, despite the three variables being the main factors affecting the DH (Table 3, Figure $1 \mathrm{~d}-\mathrm{f}$ ). Figure $1 \mathrm{~d}$ shows the response surface plot at various $\mathrm{E} / \mathrm{S}$ and substrate concentrations. The DH decreased rapidly with the increasing substrate concentration, while there was less effect on the $\mathrm{DH}$ with the increasing of $\mathrm{E} / \mathrm{S}$, which further validates there was not interaction between $\mathrm{E} / \mathrm{S}$ and substrate concentration. The response curves shown in Figure 1e and Figure 1f were comparatively smooth at lower E/S and higher substrate concentration, indicating less effect on increasing the DH when the reaction time changed within the range $30 \mathrm{~min}$ to $210 \mathrm{~min}$. This result indicates that no significant interaction existed between $\mathrm{E} / \mathrm{S}$ and reaction time and between substrate concentration and reaction time. Longer reaction times resulted in higher $\mathrm{DH}$, higher $\mathrm{E} / \mathrm{S}$ and lower substrate concentrations in the experimental range.

\subsection{Fitting the Model}

The response results shown in Table 1 were analyzed using Statistic 6.0 software. A regression analysis (Table 2) was carried out to fit mathematical models to the experimental data aiming at an optimal region for the responses studied. Predicted response $Y_{1}$ for the DH of DAM hydrolysis and $Y_{2}$ for the AOP yield rate could be expressed by the following second order polynomial equations in terms of coded values:

$$
\begin{aligned}
& Y_{1}=26.9838-1.1956 X_{1}+1.7267 X_{2}-3.6016 X_{3}+1.1299 X_{4}-1.9914 X_{1}^{2}-0.6798 X_{3}^{2} \\
& -0.5118 X_{4}^{2}-0.6538 X_{1} X_{2}-0.88125 X_{1} X_{3}+0.76875 X_{1} X_{4} \\
& Y_{2}=59.1784-1.3525 X_{1}+2.2386 X_{2}-6.2446 X_{3}+2.3572 X_{4}-3.1715 X_{1}^{2}-1.5010 X_{2}^{2} \\
& -1.0997 X_{4}^{2}
\end{aligned}
$$

where $Y_{1}$ and $Y_{2}$ are the predicted response in real value; $X_{1}, X_{2}, X_{3}, X_{4}$ the coded values of temperature, $\mathrm{E} / \mathrm{S}$, substrate concentration and reaction time, respectively.

Table 2 presents the analysis of variance (ANOVA) for the fitted quadratic polynomial model of DH and AOP yield rate. The high model $F$-value $(F=69.655$ and 39.172$)$ and the low $p$-value 
( $p<0001)$ indicate that the models were highly significant. $R_{\text {adj }}^{2}$ (adjusted determination coefficient) is the correlation measure for testing the goodness-of-fit of the regression equation between experimental and model predicted values. The higher this value, the better the degree of correlation between the observed and predicted values [20]. The value of $R_{\text {adj }}^{2}$ for Equation (1) is 0.9858 and that for Equation (2) is 0.9502 , which are reasonably close to 1 and imply that $98.58 \%$ of the total variation can be explained by model Equation (1) and $95.02 \%$ of the total variations can be explained by model Equation (2). The slope of the correlation shows that most of the actual values were under the prediction of the values. The ANOVA also shows that the lack of fit was non-significant $(p>0.05)$, which further validates the models.

Table 1. The factorial central composite design matrix for hydrolysis $\mathrm{DH}$ and yield rate: hydrolysis temperature $\left({ }^{\circ} \mathrm{C}\right)\left(X_{1}\right)$, enzyme-to-substrate ratio $(\mathrm{E} / \mathrm{S})$ (units $\mathrm{g}^{-1}$ protein) $\left(X_{2}\right)$; substrate concentration $(\%)\left(X_{3}\right)$, reaction time $(\mathrm{min})\left(X_{4}\right)$ were the four independent variables.

\begin{tabular}{|c|c|c|c|c|c|c|c|c|}
\hline \multirow{2}{*}{$\begin{array}{l}\text { Trial } \\
\text { No. }\end{array}$} & \multicolumn{4}{|c|}{ Independent Variables } & \multicolumn{2}{|c|}{ DH $(\%)$} & \multicolumn{2}{|c|}{ Yield Rate (\%) } \\
\hline & $X_{1}$ & $X_{2}$ & $X_{3}$ & $X_{4}$ & $\begin{array}{l}\text { Actual } \\
\text { Value }\end{array}$ & $\begin{array}{l}\text { Predicted } \\
\text { Value }\end{array}$ & $\begin{array}{l}\text { Actual } \\
\text { Value }\end{array}$ & $\begin{array}{l}\text { Predicted } \\
\text { Value }\end{array}$ \\
\hline 1 & 59.9 & 5852 & 6.8 & 174 & 21.29 & 21.04 & 52.54 & 52.07 \\
\hline 2 & 59.9 & 5852 & 3.2 & 66 & 27.04 & 26.21 & 59.58 & 59.15 \\
\hline 3 & 59.9 & 1898 & 6.8 & 66 & 15.07 & 15.10 & 41.47 & 40.08 \\
\hline 4 & 59.9 & 1898 & 3.2 & 174 & 28.02 & 27.86 & 57.54 & 57.05 \\
\hline 5 & 45.1 & 5852 & 6.8 & 66 & 24.21 & 24.24 & 46.68 & 47.02 \\
\hline 6 & 45.1 & 5852 & 3.2 & 174 & 30.56 & 30.40 & 63.22 & 64.46 \\
\hline 7 & 45.1 & 1898 & 6.8 & 174 & 19.5 & 20.20 & 49.32 & 49.60 \\
\hline 8 & 45.1 & 1898 & 3.2 & 66 & 24.8 & 24.92 & 57.75 & 58.07 \\
\hline 9 & 40 & 3875 & 5 & 120 & 23.84 & 23.36 & 53.89 & 52.514 \\
\hline 10 & 65 & 3875 & 5 & 120 & 18.68 & 19.34 & 46.38 & 47.97 \\
\hline 11 & 52.5 & 500 & 5 & 120 & 24.4 & 23.93 & 50.51 & 51.20 \\
\hline 12 & 52.5 & 7200 & 5 & 120 & 29.08 & 29.74 & 59.21 & 58.73 \\
\hline 13 & 52.5 & 3875 & 2 & 120 & 30.57 & 31.11 & 70.32 & 69.71 \\
\hline 14 & 52.5 & 3875 & 8 & 120 & 19.37 & 19.00 & 48.2 & 48.71 \\
\hline 15 & 52.5 & 3875 & 5 & 30 & 23.31 & 23.64 & 51.52 & 52.14 \\
\hline 16 & 52.5 & 3875 & 5 & 210 & 27.58 & 27.44 & 60.47 & 60.06 \\
\hline 17 & 52.5 & 3875 & 5 & 120 & 27.49 & 26.99 & 58.46 & 59.21 \\
\hline 18 & 52.5 & 3875 & 5 & 120 & 27.69 & 26.98 & 56.4 & 59.21 \\
\hline 19 & 52.5 & 3875 & 5 & 120 & 27.48 & 26.98 & 60 & 59.21 \\
\hline 20 & 52.5 & 3875 & 5 & 120 & 26.97 & 26.98 & 61.03 & 59.21 \\
\hline 21 & 52.5 & 3875 & 5 & 120 & 26.49 & 26.98 & 59.23 & 59.21 \\
\hline 22 & 52.5 & 3875 & 5 & 120 & 26.49 & 26.98 & 60 & 59.21 \\
\hline 23 & 52.5 & 3875 & 5 & 120 & 26.49 & 26.98 & 59.3 & 59.21 \\
\hline
\end{tabular}

The $t$-test and $p$-value were used to check the effect of each factor on DH and AOP yield rate (Table 3). The data in Table 3 indicate that all the independent variables $\left(X_{1}, X_{2}, X_{3}, X_{4}\right)$ and three quadratic terms $\left(X_{1}^{2}, X_{3}^{2}\right.$ and $\left.X_{4}^{2}\right)$ significantly affected the $\mathrm{DH}$, and there was significant interaction between temperature and the other three variables $(\mathrm{E} / \mathrm{S}$, substrate concentration and reaction time). 
Meanwhile, it can be seen that the AOP yield rate was influenced by all the four independent variables and three quadratic terms $\left(X_{1}^{2}, X_{2}^{2}\right.$ and $\left.X_{4}^{2}\right)$. Interaction between variables did not significantly impact AOP.

Table 2. The analysis of variance (ANOVA) for the fitted quadratic polynomial model of $\mathrm{DH}$ and $\mathrm{AOP}$ yield rate.

\begin{tabular}{llllll}
\hline Source & DF & SS & MS & F-value & Prob $>\boldsymbol{F}$ \\
\hline DH (\%) & & & & & \\
Residual & 11 & 343.122 & 31.193 & 69.655 & $0.0001^{* *}$ \\
Lack of fit & 11 & 4.926 & 0.448 & & \\
Pure error & 5 & 3.199 & 0.639 & 2.22405 & 0.125 \\
Cor total & 6 & 1.7264 & 0.288 & & \\
Regression & 22 & 348.048 & & & \\
& & $R^{2}=0.9859$ & $R_{\text {Adj }}^{2}=0.9858$ & & $0.0001^{* *}$ \\
Yield rate (\%) & & & & \\
Residual & 11 & 928.407 & 84.401 & 39.172 & \\
Lack of fit & 11 & 23.701 & 2.1546 & & \\
Pure error & 5 & 10.674 & 2.135 & 0.983 & \\
Cor total & 6 & 13.027 & 2.171 & & \\
Regression & 22 & 952.108 & & & \\
& & $R^{2}=0.9751$ & $R_{\text {Adj }}^{2}=0.9502$ & & \\
\hline
\end{tabular}

** significant at 0.01 .

Table 3. Significance of regression equation coefficients for the DH and AOP yield rate.

\begin{tabular}{lllllllll}
\hline Variable & \multicolumn{3}{c}{ DH } & \multicolumn{5}{c}{ Yield Rate } \\
\cline { 2 - 8 } & $\begin{array}{l}\text { Regression } \\
\text { coefficients }\end{array}$ & $\begin{array}{l}\text { Standard } \\
\text { error }\end{array}$ & $\boldsymbol{t}$-value & $\boldsymbol{p}$-value & $\begin{array}{l}\text { Regression } \\
\text { coefficients }\end{array}$ & $\begin{array}{l}\text { Standar } \\
\boldsymbol{d} \text { error }\end{array}$ & $\boldsymbol{t}$-value & $\boldsymbol{p}$-value \\
\hline$X_{1}$ & -0.8936 & 0.1810 & 6.6025 & 0.0002 & -0.7163 & 0.3971 & 3.4050 & 0.0143 \\
$X_{2}$ & 0.9445 & 0.1678 & 9.5353 & 0.0001 & 0.8618 & 0.3682 & 5.6358 & 0.0005 \\
$X_{3}$ & -0.9864 & 0.1810 & 19.8892 & 0.0001 & -0.9785 & 0.3971 & 15.7214 & 0.0001 \\
$X_{4}$ & 0.8830 & 0.1678 & 6.2399 & 0.0002 & 0.8729 & 0.3682 & 5.9345 & 0.0004 \\
$X_{1} X_{1}$ & -0.9631 & 0.1810 & 11.8620 & 0.0001 & -0.9332 & 0.3971 & 8.6124 & 0.0001 \\
$X_{2} X_{2}$ & -0.0965 & 0.1678 & 0.3214 & 0.7891 & -0.7757 & 0.3682 & 4.0760 & 0.0052 \\
$X_{3} X_{3}$ & -0.7736 & 0.1810 & 4.0490 & 0.0054 & 0.0447 & 0.3971 & 0.1484 & 0.9016 \\
$X_{4} X_{4}$ & -0.6767 & 0.1678 & 3.0486 & 0.0247 & -0.6691 & 0.3682 & 2.9863 & 0.0272 \\
$X_{1} X_{2}$ & -0.6401 & 0.2365 & 2.7632 & 0.0381 & 0.5982 & 0.5189 & 2.4761 & 0.0584 \\
$X_{1} X_{3}$ & -0.7468 & 0.2365 & 3.7247 & 0.0088 & 0.1339 & 0.5189 & 0.4480 & 0.7097 \\
$X_{1} X_{4}$ & 0.6998 & 0.2365 & 3.2492 & 0.0182 & 0.0667 & 0.5189 & 0.2216 & 0.8536 \\
\hline
\end{tabular}

\subsection{Optimization of Hydrolysis Parameters and Validation of the Model}

To validate the practicability and veracity of the equation, the experiment was run at optimum conditions within the experimental range obtained from the above study. DH and yield rate were obtained at the optimum level were $34.10 \pm 5.25 \%$ and $72.42 \pm 2.27 \%(N=3)$, respectively. This is significantly in agreement with the calculated values $(p>0.05)$. The results of analysis confirmed that 
the response models were adequate for reflecting the expected optimization, and the model of Equation (1) and Equation (2) were satisfactory and accurate.

\section{Experimental Section}

\subsection{Materials}

Neutrase $0.8 \mathrm{~L}\left(1.6 \times 10^{5}\right.$ units $\mathrm{g}^{-1}$ protein) was purchased from Novozymes A/S (Bagsvaerd DK-2880, Denmark) and N120P $\left(2.2 \times 10^{5}\right.$ units $\mathrm{g}^{-1}$ protein) was purchased from Co. Kerry (Prince's Street, Tralee, Ireland). Commercial defatted almonds meal (DAM), obtained from Aolike Ecogocal Agriculture Co.ltd (Xinjiang, China), was used as hydrolysis action substrate. The chemical composition of DAM was as follows: protein, 51.28\%; moisture, 3.5\%; lipid, 7.0\%; ash, 4.8\%; and crude fiber, $7.81 \%$ (all data were provided by the supplier). All chemicals used in this investigation were of analytical grade and purchased from Beijing Chemicals Co. (Beijing, China).

\subsection{Preparation of Apricot Kernel Oligopeptides}

In the present study, DAM was hydrolyzed with Neutrase $0.8 \mathrm{~L}$ which cleaves peptides bonds with broad specificity, produced by Bacillus amyloliquefaciens. N120P is a food-grade enzyme produced by Bacillus subtilis, which has been shown to hydrolyse peptides with aromatic amino acids and Ala, Val. Because $20 \%$ of the amino acids are Ala, Val and Phe, and so on [1,21,22], these proteases can hydrolyse apricot kernel protein effectively. The process of hydrolysing DAM to prepare almond oligopeptides (AOP) was performed in a jacketed glass reactor connected to a thermostatically controlled water heater (CS501-SP, SiDa Science Instruments Inc. Chongqing Province, China) to maintain a constant temperature of suspension for the whole hydrolysis processing. The DAM was mixed with water and the substrate concentration was $2 \%, 3.2 \%, 5 \%, 6.8 \%, 8 \%$, respectively. Prior to hydrolysis, the DAM solution was stirred for $15 \mathrm{~min}$ at the pretreatment temperature of $85{ }^{\circ} \mathrm{C}$. During hydrolysis, enzyme-to-substrate ratio was 550-7,200 units $\mathrm{g}^{-1}$ protein. According to our preliminary research, the suspension $\mathrm{pH}$ was maintained at 6.5 by the addition of $1 \mathrm{~mol} \mathrm{~L}^{-1} \mathrm{NaOH}$, the enzyme ratio of Neutrase 0.8 to $\mathrm{N} 120 \mathrm{P}$ was $2: 1$. The hydrolysis process was terminated by heating the reactants at $90{ }^{\circ} \mathrm{C}$ for $10 \mathrm{~min}$, followed by cooling to room temperature and centrifugation of the suspension at $4200 \mathrm{rpm}$ for $15 \mathrm{~min}$ to separate the solid and liquid phases. Finally, the supernatant of hydrolysate were freeze-dried at $-40{ }^{\circ} \mathrm{C}$ and stored at $20^{\circ} \mathrm{C}$ for further use.

The $\mathrm{DH}$, which is defined as the percentage of peptide bonds cleaved by protease, was determined according to the OPA method [23]. The soluble nitrogen was determined by a modified Lowry's method using bovine serum albumin as a standard [24], and the AOP yield rate was assayed with the methods described by Jang et al. [25].

\subsection{Experimental Design}

According to our preliminary experiments, the hydrolysis parameters, including hydrolysis temperature $\left(X_{1}\right)$, enzyme-to-substrate ratio $(\mathrm{E} / \mathrm{S})\left(X_{2}\right)$, substrate concentration $\left(X_{3}\right)$ and reaction time $\left(X_{4}\right)$, were optimized as independent variables $(K=4)$, while other related hydrolysis parameters, such as $\mathrm{pH}$ and Neutrase-to-N120P dosage ratio, were maintained at the optimum level 6.5 and 2:1, 
respectively, according to our preliminary research based on DH and yield rate. The two dependent variables to evaluate the effect of hydrolysis were $\mathrm{DH}(\%)\left(Y_{1}\right)$ and yield rate $(\%)\left(Y_{2}\right)$ of AOP. The independent variables were optimized using a central composite rotatable design (CCRD) containing five levels for each independent variable, coded as $-1.682,-1,0,+1,+1.682$. The ranges of the independent variables are given in Table 4. Table 1 listed the central composite design consisting of 16 experimental points and seven central designs. Each hydrolysis experiment was run in duplicate.

Table 4. Coded settings of the independent variables for DAM hydrolysis, according to central composite rotatable design: hydrolysis temperature $\left({ }^{\circ} \mathrm{C}\right)\left(X_{1}\right)$, enzyme-to-substrate ratio $(\mathrm{E} / \mathrm{S})$ (units $\mathrm{g}^{-1}$ protein) $\left(X_{2}\right)$; substrate concentration $(\%)\left(X_{3}\right)$, reaction time $(\mathrm{min})$ $\left(X_{4}\right)$ were the four independent variables.

\begin{tabular}{lcccc}
\hline Coded & \multicolumn{4}{c}{ Independent Variables } \\
\cline { 2 - 5 } Level & $\boldsymbol{X}_{\mathbf{1}}\left({ }^{\circ} \mathbf{C}\right)$ & $\boldsymbol{X}_{\mathbf{2}}\left(\right.$ units $^{-\mathbf{- 1}}$ protein $)$ & $\boldsymbol{X}_{\mathbf{3}}(\boldsymbol{\%})$ & $\boldsymbol{X}_{\mathbf{4}}(\mathbf{m i n})$ \\
\hline $1.682(+\gamma)$ & 65 & 7200 & 8 & 210 \\
1 & 59.9 & 5852 & 6.8 & 174 \\
0 & 52.5 & 3875 & 5 & 120 \\
-1 & 45.1 & 1898 & 3.2 & 66 \\
$-1.682(-\gamma)$ & 40 & 550 & 2 & 30 \\
\hline
\end{tabular}

Experimental data were fitted to a quadratic polynomial model and regression coefficients obtained. The non-linear computer generated quadratic model used in the response surface was of the form:

$$
Y=\beta_{0}+\sum_{i=1}^{4} \beta_{i} X_{i}+\sum_{i=1}^{4} \beta_{i i} X_{i}^{2}+\sum_{i=1}^{4} \beta_{i j} X_{i} X_{j}
$$

where $Y$ was the predicted response, $\beta$ the intercept term, $\beta_{i}$ the linear coefficients, $\beta_{i i}$ the quadratic coefficients, $\beta_{i j}$ the interactive coefficients, and $X_{i}$ and $X_{j}$ the coded independent variables. Data were expressed as means of duplicated determinations. The responses obtained from each set of CCRD experimental design (Table 1) were subjected to multiple non-linear regressions using the Design Expert software (Statistic version 6.0, Statsoft inc., Tulsa, OK, USA). The significance of the equation parameters for each response variable was assessed by the student's- $t$ test. The level of significance was defined at $p<0.05$. The quality of fit of model was evaluated by the analysis of variance (ANOVA).

\section{Conclusions}

DAM, which was a good substrate to produce peptides, was effectively hydrolyzed by Neutrase $0.8 \mathrm{~L}$ and N120P proteinases to obtain oligopeptides with a high $\mathrm{DH}$ and yield rate. Response surface analysis was an efficient statistical analysis tool in the optimization of the hydrolysis conditions. DH and yield rate was influenced significantly by hydrolysis temperature, E/S, substrate concentration and reaction time $(p<0.05)$. For the model of $\mathrm{DH}$, all the independent variables, quadratic of temperature, substrate concentration and extraction time had highly significant effects on the response values, followed by a significant interaction effect between temperature and the other three variables. For the model of yield rate, all the independent variables, quadratic of temperature, E/S and reaction time significantly affected the response values, and there was no interaction between variables. A high 
correlation of the quadratic polynomial mathematical model was obtained and could be employed to optimize the hydrolysis of apricot kernel protein meal by Neutrase and N120P proteases. According to the preliminary work and central composite rotatable design in this study, the highest $\mathrm{DH}$ and yield rates were $34.10 \pm 5.25 \%$ and $72.42 \pm 2.27 \%$, respectively, at $\mathrm{pH} 6.5$, with a Neutrase-to-N120P

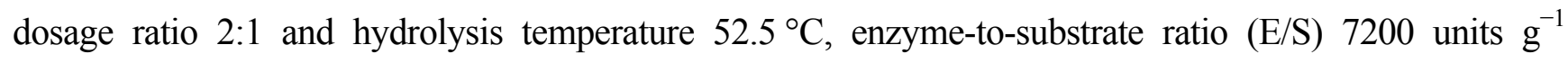
protein, and substrate concentration $2 \%$, reaction time $173 \mathrm{~min}$.

\section{Acknowledgements}

This research was funded by Major Special Project of the Xinjiang Uygur Autonomous Region (200831108).

\section{References}

1. Ahrens, S.; Venkatachalam, M.N.; Lapsley, K.; Sathe, S.K. Almond (Prunus dulcis L.) protein quality. Plant Foods Hum. Nutr. 2005, 60, 123-128.

2. Cherif, A.; Sebei, K.; Boukhchina, S.; Kallel, H.; Belkacemi, K.; Arul, J. Kernel fatty acid and triacylglycerol composition for three almond cultivars during maturation. J. Am. Oil Chem. Soc. 2004, 81, 901-905.

3. Gezer, I.; Haciseferoğulları, H.; Demir, F. Some physical properties of Hacıhalilo_glu apricot pit and its kernel. J. Food Eng. 2002, 56, 49-57.

4. Özkal, S.G.; Yener, M.E.; Bayındırlı, L. Response surfaces of apricot kernel oil yield in supercritical carbon dioxide. Food Sci. Technol. 2005, 38, 611-616.

5. Abd E1-Aal, M.H.; Hamza, M.A.; Rahma, E.H. In vitro digestibility, physicochemical and functional properties of apricot kernel proteins. Food Chem. 1986, 19, 197-211.

6. Sze-Tao, K.W.C.; Sathe, S.K. Functional properties and in vitro digestibility of almond (Prunus dulcis L.) protein isolate. Food Chem. 2000, 69, 153-160.

7. Tiwari, R.S.; Venkatachalam, M.; Girdhari, M.S.; Su, M.; Roux, K.H.; Sathe, S.K. Effect of food matrix on amandin, almond (Prunus dulcis L.) major protein,immunorecognition and recovery. Food Sci. Technol. 2010, 43, 675-683.

8. Gauthier, S.F.; Pouliot, Y., Saint-Sauveur, D. Imunomodulatory peptides obtained by the enzymatic hydrolysis of whey proteins. Int. Dairy J. 2006, 16, 197-211.

9. Iván, L.-E.; Recio, I. Antibacterial activity of peptides and folding variants from milk proteins. Int. Dairy J. 2006, 16, 1294-1305.

10. Shimizu, M.; Sawashita, N.; Morimatsu, F.; Ichikawa, J.; Taguchi, Y.; Ijiri, Y.; Yamamoto, J. Antithrombotic papain-hydrolyzed peptides isolated from pork meat. Thrombosis Res. 2009, 123, 753-757.

11. Kuba, M.; Tana, C.; Tawata, S.; Yasuda, M. Production of angiotensin I-converting enzyme inhibitory peptides from soybean protein with Monascus purpureus acid proteinase. Process Biochem. 2005, 40, 2191-2196. 
12. Wang, Y.K.; He, H.L.; Chen, X.L.; Sun, C.Y.; Zhang, Y.Z.; Zhou, B.C. Production of novel angiotensin I-converting enzyme inhibitory peptides by fermentation of marine shrimp Acetes chinensis with Lactobacillus fermentum SM 605. Appl. Microbiol. Biotechnol. 2008, 79, 785-791.

13. van Beresteijn, E.C.H.; Peeters, R.A.; Kaper, J.; Meijer, R.J.G.M.; Robben, A.J.P.M.; Schmidt, D.G. Molecular mass distribution, immunological properties and nutritive value of whey protein hydrolysates. J. Food Prot. 1994, 57, 619-625.

14. Ena, J.M.; van Beresteijn, E.C.H.; Robben, A.J.P.M.; Schmid, D.G. Whey protein antigenicity reduction by fungal proteinases and a pepsin/pancreatin combination. J. Food Sci. 1995, 60, 104-116.

15. Vázquez-Lara, L.; Tello-Solis. S.R.; Gomez-Ruiz, L.; Garcia-Garibay, M.; Rodriguez-Serrano, G.M. Degradation of $\alpha$-Lactalbumin and B-Lactoglobulin by Actinidin. Food Biotechnol. 2003, $17,117-128$.

16. Zhang, Y.; Wang, Q. Preparation of peanut functional oligopeptides by two-step-hydrolysis. Trans. Chin. Soc. Agric. Eng. 2007, 23, 258-263.

17. Wang, C.; Feng, B.; Dong, Y. Optimization of the enzymatic hydrolysis of oat bran by Protamex protease response surface method. Food Sci. Technol. 2008, 5, 134-137.

18. Gonzalez, P.; Camacho, F.; Jurado, E.; Paez, M.P.; Guadix, E.M. Enzymatic hydrolysis of whey proteins: I. Kinetic models. Biotechnol. Bioeng. 1994, 44, 523-528.

19. Zhang, Y.; Wang, Q.; Zhou, S. Peanut protein hydrolyzing by Alcalase to prepare peanut oligopeptides. Trans. Chin. Soc. Agric. Eng. 2008, 24, 275-279.

20. Ravikumar, K.; Ramalingam, S.; Krishnan, S.; Balu, K. Optimization of process variables by the application of response surface methodology for dye removal using a novel adsorbent. Dyes Pigm. 2006, 70, 18-26.

21. Sheng, X.; Wang, Z.; Xu, S. Study on functional properties and structure of sugary almond protein. Sci. Technol. Food Ind. 2008, 29, 133-136.

22. Wang, S.; Wen, Z.; Li, H. Analysis of the Nutritional Components and Contents of Sweet Apricot kernel. Beijing Agric. 2008, 9, 13-15.

23. Petersen, D.; Nielsen, P.M.; Cambmann, C. Determination of the Degree of Hydrolysis (DH) based on OPA Reaction, ED-9512723; Novo Nordisk A/S: Bagsværd, Denmark, 1995.

24. Owueu-Apenten, R.K. Food Protein Analysis: Quantitative Effecting on Processing; 1st ed.; Marcel Dekker, Inc.: New York, NY, USA, 2002; pp. 69-87.

25. Jang, A.; Lee, M. Purification and identification of angiotensin converting enzyme inhibitory peptides from beef hydrolysates. Meat Sci. 2005, 69, 653-661.

(C) 2010 by the authors; licensee MDPI, Basel, Switzerland. This article is an open access article distributed under the terms and conditions of the Creative Commons Attribution license (http://creativecommons.org/licenses/by/3.0/). 